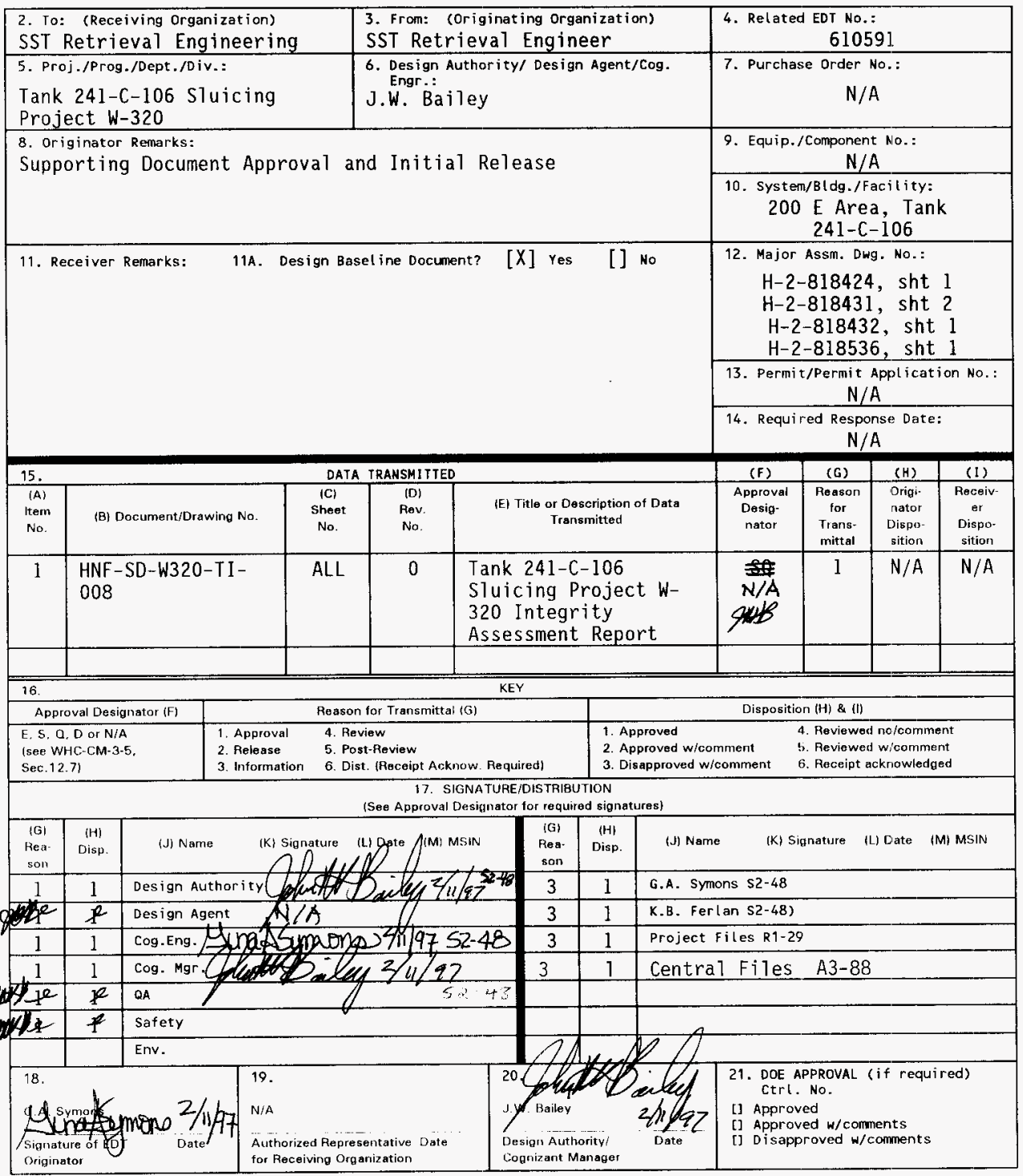

BO- $7400-172-2(05 / 96)$ GEF097 


\section{Tank 241-C-106 Sluicing Project W-320 Integrity Assessment Report}

\section{G. A. Symons}

SGN Eurisys Services Corporation, Richland, WA 99352

U.S. Department of Energy Contract DE-AC06-96RL13200

$\begin{array}{lll}\text { EDT/ECN: } & 610591 & \text { UC: } 510 \\ \text { Org Code: } & \text { O8E00 } & \text { Charge Code: D2M4E } \\ \text { B\&R Code: } & \text { EW3130010 } & \text { Tota1 Pages: } 44\end{array}$

Key Words: Integrity Assessment, Tank 241-AY-102, Tank 241-C-106, Sluicing, Pumps, WAC-173-303-640

Abstract: This Integrity Assessment Report is prepared by ICF Kaiser Hanford Co. (ICFKH) for Westinghouse Hanford Company (WHC), operations contractor and the Department of Energy (DOE), the system owner. It is a revision of the original report dated 10/26/94 (ICFKH Transmittal TR-W-320-295). The original project scope has been modified, necessitating with WAC-173-303-640.

TRADEMARK DISCLAIMER. Reference herein to any specific commercial product, process, or service by trade name, trademark, manufacturer, or otherwise, does not necessarily constitute or imply its endorsement, recommendation, or favoring by the United States Government or any agency thereof or its contractors or subcontractors.

Printed in the United States of America. To obtain copies of this document, contact: WHC/BCS Document Control Services, P.0. Box 1970, Mailstop H6-08, Richland HA 20352 2, Dhode (5092 372=2620. Fax $(509)$ 376-4989.
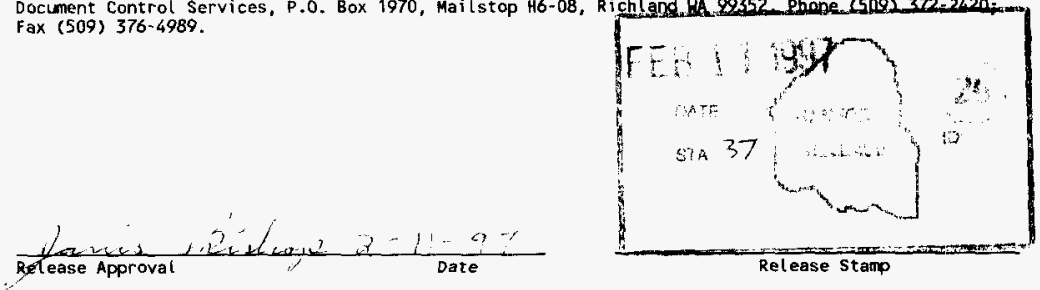

\section{Approved for Public Release}


HNF-SD-W320-TI-008, Rev. 0

Page 1 of 43

\title{
TANK 241-C-106 SLUICING
}

\section{PROJECT W-320}

\author{
INTEGRITY ASSESSMENT REPORT \\ (Design Only - Revision 1) \\ Reference: W-320-IAR-Rev 1 \\ Prepared By: \\ Karl F. Feigner, \\ ICF Kaiser Hanford Company, \\ Richland, Washington \\ - For: \\ U. S. Department of Energy \\ Contract WHC-380393
}




\section{Table of Contents}

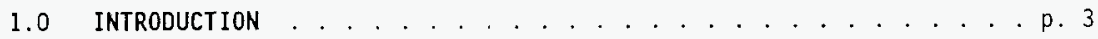

1.1 General Comments

1.2 System Description

1.3 Scope

1.4 Comments on Certification

2.0 ASSESSMENT . . . . . . . . . . . . . . . . p. 7

2.1 Codes and Standards

2.2 Waste Characterization

2.3 Potential for Corrosion Failure

2.4 Effects of Vehicular Traffic

2.5 Foundation Loading

2.6 Effects of Frost Heave

2.7 Pressure Effects

2.8 Thermal Effects

2.9 Seismic Effects

3.0 STRUCTHRAL INTEGRITY ASSESSMENT CERTIFICATION . . . . . . . . . 11

ATTACHMENTS: Appendix I (References) . . . . . . p. 12 Appendix II (Waste Characterization) . . p. 15 Appendix III (Calculations List) .... p. 19 Appendix IV (Drawing List) . . . . . . p. 21 Appendix V (Drawings) ........ . . 27 H-2-818424, Project site Plan

$\mathrm{H}-2-818431$, sheet 1 of 2, 241-C Tank Farm site Plan H-2-818432, 241-AY Tank Farm Site Plan

you Hedraulic Diagram

Appendix VI (Corrosion Study) . . . . . p. 32 


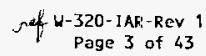

\subsection{INTRODUCTION}

\subsection{General Comments}

This Integrity Assessinent Report is prepared by ICF Kaiser Hanford Co. (ICFKH) for Westinghouse Hanford company (WHC), operations contractor and the Department of Energy (DOE), the system owner. It is a revision of the original report dated $10 / 26 / 94$ (ICFKH Transmittal TR-W-320-295). The original project scope has been modified, necessitating this revised report, which is prepared in accordance with WAC-173-303-640.

The purpose of the project is to remove high heat generating solids from Tank 241-C-106, which is a single shell underground storage tank. Present $1 \mathrm{y}$, approximately $100,000 \mathrm{Btu} / \mathrm{hr}$ of heat energy is generated by radioactive decay within the sludge layer contained in Tank 24l-C-106. Various radioactive elements are contained within the sludge, however, strontium is the most important. To prevent the tank contents from generating sufficient heat to damage the tank shel1, about 6,000 gallons per month of water is added to the tank. The water absorbs the heat energy and cools the tank contents by evaporating. The water also prevents the sludge layer from drying.

Dependence upon water addition to control the heat generated within the tank is undesirable. Should a leak develop, the water additions will increase the leakage to the soil column. Additionally, the Tri-Party Agreement requires that a full scale waste retrieval technology demonstration for single shell storage tanks be performed prior to $10 / 97$. Project $W-320$ fulfills this requirement.

The solids are in the form of a sludge cake located on the bottom of the tank, and will be removed from the tank by "sluicing". "sluicing", is a term used to describe the breaking up of a sludge cake by using a high pressure water jet, generated by an articulated nozzle (sluicer), to create a slurry suitable for pumping. Once the slurry is produced, it will be pumped out of the tank and transported, via a pipeline, to Tank 241-AY-102 where the solids will be allowed to settle. Solids will be stored in this tank for future treatment and disposal. Tank 241-AY-102 is a newer double shell stainless steel storage tank, which is also located underground. This tank can safely store the contents of Tank 241-C-106.

Water for the sluicing operation will be supernatant liquid, chemically adjusted for $\mathrm{pH}$, recirculated from Tank 241-AY-102. A pipeline will be used to transport the supernatant liquid from Tank 241-AY-102 to Tank 24l-C-106. Initially, sluicing operations will begin by adding buffered water to the existing supernate in 
Tank 241-AY-102. A total inventory of approximate $7 y$ 500,000 gallons of supernate is required for sluicing operations to be performed.

A submersible pump (P-0621) instalied in Tank 241-AY-102, and a booster pump installed in Sluice Pit 24l-AY-O2E will provide the motive force to transport the supernatant to the sluicer. As slurry is produced, it will be removed and transported to Tank 241-AY-102, also by pipeline. A submersible pump (P-1361) installed in Tank 241-C-106, and a booster pump (P-1362) installed in Pump Pit 241-C-06A will provide the motive force necessary to transport the slurry to Tank 241-AY-102. Fluid residence time within Tank 241-AY-102 is sufficient to permit the majority of the solids to settle before supernatant liquid is returned to Tank 241-C-106 for sluicing, reference [7].

Refer to the drawings listed below for the physical arrangement of the tankage. Reduced copies of these drawings are contained in Appendix $V$.

- H-2-818424, Project Site Plan;

- H-2-818431, Sheet 1 of 2, 241-C-Tank Farm Site Plan;

- H-2-818432, 24l-AY-Tank Farm Site Plan.

\subsection{System Description}

Project scope has been reduced torreflect a minimized cost approach implemented to trim estimated project cost by simplifying the waste transfer system. Primarily, deletions have been effected in auxiliary functions, or systems. Transfer piping design remains unchanged, however, less automation is incorporated for operation. Deleted items are as follows:

- Supporting structures such as the control room, lunch room, and sanitary facilities. Required control instrumentation will be installed in a construction trailer for the "C" Tank Farm, and on a panel board located in an "AY" Tank Farm electrical equipment building.

- Instrumentation such as the automated "feedback flow control system", and flow totalizer have been deleted. The remote in-tank imaging system is simplified.

- In-tank slujcers reduced from two to one.

- Pump, piping, and leak detection instrumentation for heel pit 241-C-06B.

Components included in the assessment are as follows: 
Juf $U-320-1$ AR-ReV 1 Page 5 of 43

Two new waste transfer pipelines that connect Tank 24l-C-106 with Tank 241-AY-102. One pipeline will be used to transport supernatant 1iquid from Tank 241-AY-102 to Tank 241-C-106. The other pipeline will be used to transport slurry from Tank 241-C-106 to Tank 241-AY-102. The slurry pipeline begins at Pump Pit 241-C-06A, located above Tank 241-C-106, and routed to Pump Pit 241-AY-02A, located above Tank 241-AY-102. Inside Pump Pit 241-AY-02A the pipeline connects to Distributor D-062l, where by the slurry enters the tank. The other, "sluice", pipeline begins in sluice Pit 241-AY-02E, located above Tank 241-AY-102, and is routed to Sluice Pit 24]-C-06C, located above Tank 241-C-106, where it connects to the sluicer.

Each pipeline is approximately 1550 lineal feet in length. They are installed near grade and bermed for shielding. Each pipeline is a double pipe (pipe within a pipe) design. The carrier pipe is 4 inch diameter, schedule $40,304 \mathrm{~L}$ stainless steel pipe. The encasement pipe is 6 or 8 inch diameter, schedule 40, Al06 Gr. B carbon steel. Eight inch diameter encasement pipe is used at bends to provide space for thermal expansion of the carrier pipe. An impressed current cathodic protection system will be installed to prevent soil induced corrosion damage to the encasement pipe.

The new piping will have electronic leak detection instrumentation installed at low points that will activate both local and remote panel-board alarms in the event of a leak. New leak detection instruments will be installed in pits 241-C-06A, and 241-C-06C. Existing leak detection instruments located in pits 241-AY-02A, and 24l-AY-02E will be incorporated into the system.

Pits 241-C-06A, 241-C-06C, 241-AY-02A, and 241-AY-02E are existing concrete structures located below grade, but directiy above their respective tanks. Originally plans included applying a coating to the internal surfaces of the pits; however, this element of the design has been removed. This issue was discussed and agreed upon by representatives of WDOE, WHC, and DOE-RL, reference [12]. Visual inspections conducted while preparatory work was performed during 1994 indicate that the pits are water tight. An observation using video equipment was made during mid october. This observation indicated that there was standing water contained within the pits. The water accumulation resulted from plugged pit drains. Later observations during mid November indicated that the water level was unchanged. Therefore, it appears that water neither migrates into or out of the pits. 
Design liquid flow rate for each pipeline is $350 \mathrm{gpm}$. If a complete rupture of one of the carrier pipes occurs, provisions are included to route the leakage directly to the tanks through high capacity drains. These drains are designed to carry 3 to 4 times the pipeline flow rate. Sump pumps will be installed to remove minor liquid accumulations. As a backup to the leak detection instrumentation, the pits will be visually inspected periodically using manual remote video cameras.

Tank 24l-C-106 HVAC ducting. This ducting is used to draw vapor from the tank head space, cool it, and then recirculate most of the vapor back to the tank. After treating, some of the vapor will be exhausted to the atmosphere.

The ducting includes a recirculation fan, condenser, moisture separator, and heating coil. The condenser is intended to cool the incoming vapor. As condensate forms, it will be collected, and returned to the tank using a double pipe drain. The moisture separator is intended to remove entrained liquid that may carry over from the condenser. Liquid that is removed from the vapor stream will be returned to the tank using a double pipe drain. The heating coil will be employed to elevate the temperature of the return vapor above saturation to minimize condensate formation within the return ducting. In addition to the heating coil, all above ground ducting is insulated. The inlet pipe from the tank to-the process bldg. (condenser) is not insulated. This pipe is all welded and will be inspected on a routine basis.

A single pipe design is employed for the ducting. Construction materials are schedule $40 \mathrm{~S} 304 \mathrm{~L}$ stainless stee pipe. Sizes are 10 inch diameter, 8 inch diameter, and 6 inch diameter. Ducting routed from Tank $241-\mathrm{C}-106$ to the condenser is 10 inch diameter. Ducting routed from the condenser to the moisture separator, and from the condenser to the exhaust skid is 6 inch diameter. Ducting routed from the moisture separator to the recirculation fan is also 6 diameter. Ducting routed from the fan to the tank is 8 inch diameter. The condenser, moisture separator and fan are located within the Process Building.

\subsection{Scope}

This IAR is based on a design assessment performed in accordance with WAC-173-303-640(3)(a) for the piping described in paragraph 1.2 above. Two Chapter 173-303 WAC requirements are not addressed in this report. The first is the development of a schedule for system inspections after operations begin. The second is the 


\begin{abstract}
Mif $W-320-I A R-R e v 1$
Page 7 of 43
development of system post closure plans. Both of these items are outside of the design assessment scope, and therefore, should be addressed by the system owner/operator.
\end{abstract}

\title{
1.4 Comments on Certification
}

Paragraph 3.0 contains a certificate attesting to the accuracy of the information presented in this report. The certificate is signed and sealed by an Independent Qual ified Registered Professional Engineer (1QRPE) in accordance with WAC-173-303$810(13)(a)$.

\subsection{ASSESSMENT}

The system described above, paragraph 1.2, is adequately designed to prevent failure caused by corrosion or by structural loads imposed by the system's intended service. However this conclusion is based on limiting the maximum operating temperature to 140 degrees $F$, and the maximum pressure to $480 \mathrm{psig.} \mathrm{Refer} \mathrm{to} \mathrm{references.} \mathrm{[1],} \mathrm{and} \mathrm{[6]} 1$ isted in Appendix I for a complete description of the system's intended service.

ICFKH commissioned a corrosion study to determine the transfer piping material's susceptibility to corrosion degradation. The study indicated that the probable mode of failure for the transfer piping would result from pitting caused by the presence of caustic chemicals contained within the wastes. Based on experimental evidence, damage resulting from pitting would be negligible at temperatures below 140 degrees $F$. Experimental evidence describing the performance of $304 \mathrm{~L}$ stainless steel in caustic environments at temperatures above 140 degrees $F$. is not available. Therefore, it was recommended that corrosion studies be performed, if it was desired to exceed an operating temperature of 140 degrees $F$. The HVAC ducting was not directly addressed in the study. However, the ducting is constructed from materials similar to the carrier piping. Therefore, the ducting is suitable for the service. A copy of this study is attached in Appendix VI.

Reference [1] states that the system must have a 2 year 1 ife, and be capable of operating at 180 degrees F. Discussions with Project Management personnel confirm that operating procedures will be initiated to 7 imit the operating temperature to 120 degrees $F$. Therefore, if the system is operated as planned, the piping will be resistant to the corrosive effects of the wastes.

Overall, it is concluded that system design is consistent with a design that is typical for a 20 year 1 ife. These results are based on review of the applicable codes, standards, design, and construction documents. Design documents include the Functional Design Criteria ref. [1], calculations (1isted in Appendix III), and drawings (1 isted in Appendix IV). Construction documents include the construction specifications, 
and procurement specifications listed in Appendix I references [2], [3], [4], and [5]. The following paragraphs 2.1 through 2.9 discuss specific considerations for the design assessment.

2.1 Codes and Standards used as a basis for design are as follows:

"Chemical Plant and Petroleum Refinery Piping", ASME B31.3, 1993.

"Forged or Rolled Alloy-steel Pipe Flanges, Forged Fittings, and Valves and Parts for High-temperature Servjce", ASTM, A 182, 1992.

"Seamless and Welded Austenitic Stainless Steel Pipes", ASTM, A$132,1992$.

"Seamless and Welded Austenitic Stainless Steel Tubing for General Service", ASTM, A-269, 1992.

"Alloy-steel and Stainless Steel Bolting Material for Hightemperature Service", ASTM A-193, 1992.

"Carbon and Alloy Steel Nuts for Bolts for High-pressure and Hightemperature Service", ASTM A-194, 1992.

"Boiler and Pressure Vessel Code; Section V, Nondestructive Examination", ASME, 1992.

"Boiler and Pressure Vessel Code; Section IX, Qualification Standards for Welding and Brazing Procedures, Welders, Brazers, and Welding and Brazing Operators", ASME, 1992.

"Seamless Carbon Steel Pipe for High-temperature Service", ASTM, A $106,1991$.

"Structural Steel", ASTM, A-36, 1991.

"Manual of Steel Construction", 9th ed., ASD.

"Steel Bars, Carbon, Cold Finished, Standard Quality", ASTM A-108, 1990.

"Heat-resisting Chromium and Chromium-nickel Stainless Steel

Plate, Sheet and Strip for Pressure Vessels", ASTM, A-240, 1992.

"Uniform Building Code", International Conference of Building Officials, 1991.

"Control of External Corrosion on Underground or Submerged Metallic Piping Systems",, NACE International, RP0169, 1992. 
"Control of External Corrosion on Metallic Buried, Partially Buried, or Submerged Liquid Storage Systems", NACE internationa1, RP0285, 1985 .

\subsection{Waste Characterization}

The waste characterization was reviewed to evaluate the compatibility of the wastes and materials. Wastes are characterized in the attachments included in Appendix 11 . The aqueous mixed waste contains 1 to 1000 ppm quantities of inorganic salts, metals, and organic materials. The waste is classified as transuranic (TRU) as well as high-heat complexed radioactive. Heat is generated by the radioactive decay of strontium, reference [25]. The wastes are deposited in layers within the tank, and were generated by several different processes that were employed in succession.

Beginning with the layer nearest to the bottom, wastes originated as follows: uranium recovery operations waste, Purex cladding waste, Purex sludge, $B$ plant low level waste, and a supernate layer resulting primarily from the addition of water in the amount of $6000 \mathrm{gals}$. per month for cooling.

After the wastes have been transferred to an underground double shell storage tank (241-AY-102), the wastes will not be susceptible to ignition, or unstable. They do not react violently with water, or form an explosive mixture. Analysis, based on the characterization, indicates that there is more than twice the required amount of water to suppress the limiting exothermic reaction that might be postulated resulting from the presence of organic carbon. The analysis assumes that all of the organic carbon present is in the form of sodium acetate. Additionally, it was determined that plutonium concentration is so minimal that criticality can not be reached prior to, during, or following waste transfer. Existing tank agitators can be employed, if necessary, to ensure the slow release of potential flammable gas. The gas can then be removed from the tank be the existing HVAC system.

\subsection{Potential for Corrosion Failure}

Piping-materials for the carrier pipe are schedule $40304 \mathrm{~L}$ stainless steel, and for the encasement pipe are schedule 40 ASTM A53 carbon steel. A study was performed by an independent corrosion expert, he found that the carrier pipe is resistant to the chemical and radioactive species listed in the waste characterization (Appendix II), a copy of this study is included in Appendix VI. Based on this study it can be concluded that the potential for failure caused by internal corrosion is very low. The potential for failure caused by soil induced corrosion is also very low. An impressed current cathodic protection system has 
been designed by a cathodic protection expert to protect the encasement piping.

No deieterious effects are expected to occur to tank 241-AY-102 as a result of the waste transfer. Concentrations of hydroxide, nitrate and nitrite, as well as the average temperature will remain within tank acceptable limits for these parameters. These parameters influence corrosion of tank walls.

A future decision may be made to increase the hydroxide ion molarity of the sluicing fluid to facilitate sludge removal. Molarity may be increased from a level of less than IM to about $3 M$ by the addition of $\mathrm{NAOH}$. Published Experimental data indicates that this change will not adversely affect corrosion of the piping or tank materials.

\subsection{Effects of Vehicular Traffic}

The interconnection piping between the two tanks is located below grade. Most of the piping is located in areas that do not have vehicular traffic. Sections of the piping that will have vehicles crossing over the top have been designed to withstand the loading of heavy trucks. This capability is demonstrated by strength calculations performed during piping design.

\subsection{Foundation Loading}

Calculations were performed to determine the suitability of the footings, and pipe supports. These calculations demonstrate that footings and supports are properly designed.

\subsection{Effects of Frost Heave}

Piping is protected from the potential effects of frost heave. Underground piping is located at depths greater than 36 inches, which is the accepted 1 imit for the frost zone. Above grade piping is insulated and electric heat traced. Above grade HVAC ducting is insulated. As mentioned above, there is a section of HVAC piping that is not insulated. This section will be visually inspected on a routine basis and the internal airstream is expected to be about $95 \mathrm{~F}$.

\subsection{Pressure Effects}

Design calculations for both the carrier and containment piping are based on an internal pressure of $480 \mathrm{psig.} \mathrm{Maximum} \mathrm{sustained}$ stress resulting from the design pressure is $55 \%$ of yield strength. Estimated operating pressure at design flow is 310 and $346 \mathrm{psig}$ for the sluice and slurry lines respectively. This estimate is based on the required pump operating head of 640 feet for each line. Specific gravity for the slurry line is 1.25 and 


\begin{abstract}
for the sluice line is 1.12. Maximum sustained stress includes the effects of the weight of the piping, including contents, and maximum pressure. Therefore it can be concluded that the piping design is sufficient to withstand the effects of internal pressure.

Design pressure for the HVAC ducting is \pm 40 inches water gage. Based on the calculations performed for the transfer piping, pressures are far below the maximum pressure for the ducting.

After the piping is constructed, it will be hydrotested in accordance ASME B31.3.
\end{abstract}

int U-320-IAR-ReV

Page 11 of 43

\title{
2.8 Thermal Effects
}

The transfer piping system was analyzed to determine the effect of heating the pipe from ambient to operating temperature. Resulting maximum stress from this condition is $68 \%$ of yield strength. Based on this analysis, the piping system is designed with sufficient flexibility to permit thermal growth resulting from the operating conditions.

\subsection{Seismic Effects}

The transfer piping-stress calculations include an evaluation of the effects of an UBC-1991 seismic zone $2 B$ event. Resulting maximum stress caused by this condition is $24 \%$ of yield strength.

\subsection{STRUCTURAL INTEGRITY ASSESSMENT CERTIFICATION}

"I certify under penalty of 7 aw that this document and all attachments were prepared undex-my direction or supervision in accordance with a system designed to assure that qualified personnel properly gather and evaluate the information submitted. Based on my inquiry of the person or persons who manage the system, or those persons directly responsibie for gathering the information, the information submitted is, to the best of my knowledge and belief, true, accurate and complete. I am aware that there are significant penalties for submitting false information, including the possibility of fine and imprisonment for knowing violations."

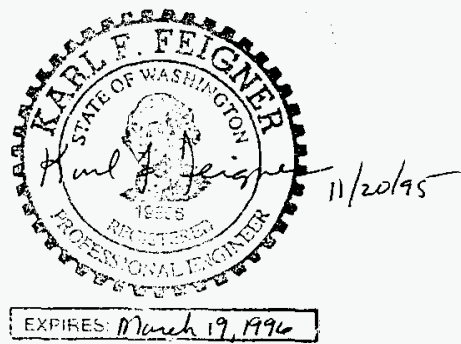


HNF-SD-W320-TI-008, ReV. 0

rut W-320-IAR ReV 1

Page 12 of 43

\section{Appendix I}

(References) 


\section{References}

[1] Functional Design Criteria "Tank 241-C-106 Waste Retrieval, Project W320", WHC-SD-W320-FDC-001 ReV. 3, 5/25/95.

[2] Construction Specification for "Tank 241-C-106 Sluicing, Package I - C Sitework/Interfarm Piping System", W-320-C1, 5/11/94.

[3] Construction Specification for "Tank 241-C-106 Sluicing, Package IV - AY Tank Farm", W-320-C7 Rev. 0, 5/21/95.

[4] Construction Specification for "Tank 241-C-106 Sluicing, Package III - C Tank Farm", W-320-C5 Rev. 0, 8/11/95.

[5] Procurement Specification for "Pump, Submersible", W-320-P17, 4/28/94.

[6] Estey, S. D., "Project W-320 Tank 241-C-105 Sluicing Process Flowsheet", WHC-SD-W320-TI-002, Rev. 0, 3/31/94.

[7] ETmore, M. R., "Materials Recommendations for C-106/AY-102 S]urry Transport Pipelines", Pacific Northwest Laboratory RET-001, 11/93.

[8] Norton, M. V. and Rector, D. R., "Preliminary Summary Report Settling Assessment for Project $W-230$, Tank 241-C-106 Sluicing", Pacific Northwest Laboratory RET-002, 2/94.

[9] Daume, J. T. and Powel1, M. R., "Project W-320: Chemical Characterization of Tank C-106", Pacific Northwest Laboratory RET-003, $11 / 93$.

[10] Ligotke, M. W., "Aerosol Concentration and Visibility in C-106 During Planned Sluicing", Pacific Northwest Laboratory RET, 12/93.

[11] "Final Report of Geotechnical Engineering Studies W-320 Waste Retrieval and Sluicing System 200 East Area, Hanford Site", Shannon \& Wilson, Inc., $\overline{4 / 94}$.

[12] Meeting Minutes, "Discussion of Interim Status Requirements, Pump and Sluice Pits at Tank Farm 241-C, Sluicing of Tank 241-C-106", 6/27/95.

[13] Computer Program "STAB" (Seismic and Thermal Analysis of Buried Piping), ver. 0.

[14] Computer Program "Auto Pipe" Ver 4.5, Engineering Design Automation.

[15] "Flow of Fluids Through Valves, Fittings, and Pipe", $25^{\text {th }}$ Printing, Technical Paper No. 410, Crane, 1985. 
Vir- W-320-IAR ReV 1

Page 14 of 43

[16] Yeh, G. C. K., "Hand Calculation of Seismic and Thermal Stresses in Buried Pipe", ASME PVP Volume - 77, June 1983.

[17] Goodling, E. C., "Flexibility Analysis of Buried Pipe", ASME PVP Vol. 82, June 1978.

[18] "Safety Equipment List for 241-C-106 Waste Retrieval, Project W-320", WHC-SD-WM-SEL-033 Rev. 1.

[19] "Standard Arch-Civil Design Criteria", SDC 4.1 Rev. 11.

[20] Computer software "Images 30". ver. 2.0 (For Frame Structures), Celestial software Inc. 1990.

[21] Baumeister and Marks, "Standard Handbook for Mechanical Engineers", $7^{\text {th }}$ Ed.

[22] Blogett, 0.W., "Design of Welded Structures", $8^{\text {th }}$ Printing, 1975.

[23] DOE 6430.1A.

[24] "Manual of Steel Construction Allowable Stress Design", AISC, $9^{\text {th }}$ Ed., 1989.

[25] "Environmental Assessment Tank 241-C-106, Past-Practice Sluicing Waste Retrieval Hanford Site, Richland, Washington", U.S. Department of Energy, Richland Operations Office, Aug. 1994.

[26] Acceptance Inspection P1an for "Project-W-320 Tank 241-C-106 Sluicing ICF-KH Development Control Design of In-Tank Equipment Removal", IP-W$320-6,5 / 11 / 94$.

[27] Acceptance Inspection Plan for "Project W-320 Tank 241-C-106 S1uicing Strongback", IP-W-320-2, 2/2/94.

[28] Acceptance Inspection Plan for "Project W-320 Tank 24l-C-106 Sluicing Flexible Receiver Assemblies", IP-W-320-3, 2/16/94.

[29] Acceptance Inspection Plan for "Project W-320 Tank 241-C-106 Sluicirig Lifting Beam", IP-W-320-5, 3/11/94.

[30] Acceptance Inspection Plan for "Project W-320 Tank 241-C-106 Sluicing Portable Instrument House Trailer", IP-W-320-4, 3/11/94.

[31] Peckner, D. and Bernstein, I. M., Handbook of Stainless Steels, McGrawHil Book Company, 1977.

[32] Schweitzer P. A., Corrosion Resistance Tables (Metals, Plastics, Nonmetallics, and Rubbers), Second Edition, Marcel Dekker, Inc., 1986. 
HNF-SD-W320-TI-008, Rev. 0

H-320-IAR ReV 1

Page 15 of 43

\section{Appendix II}

(Waste Characterization) 
Waste Characterization

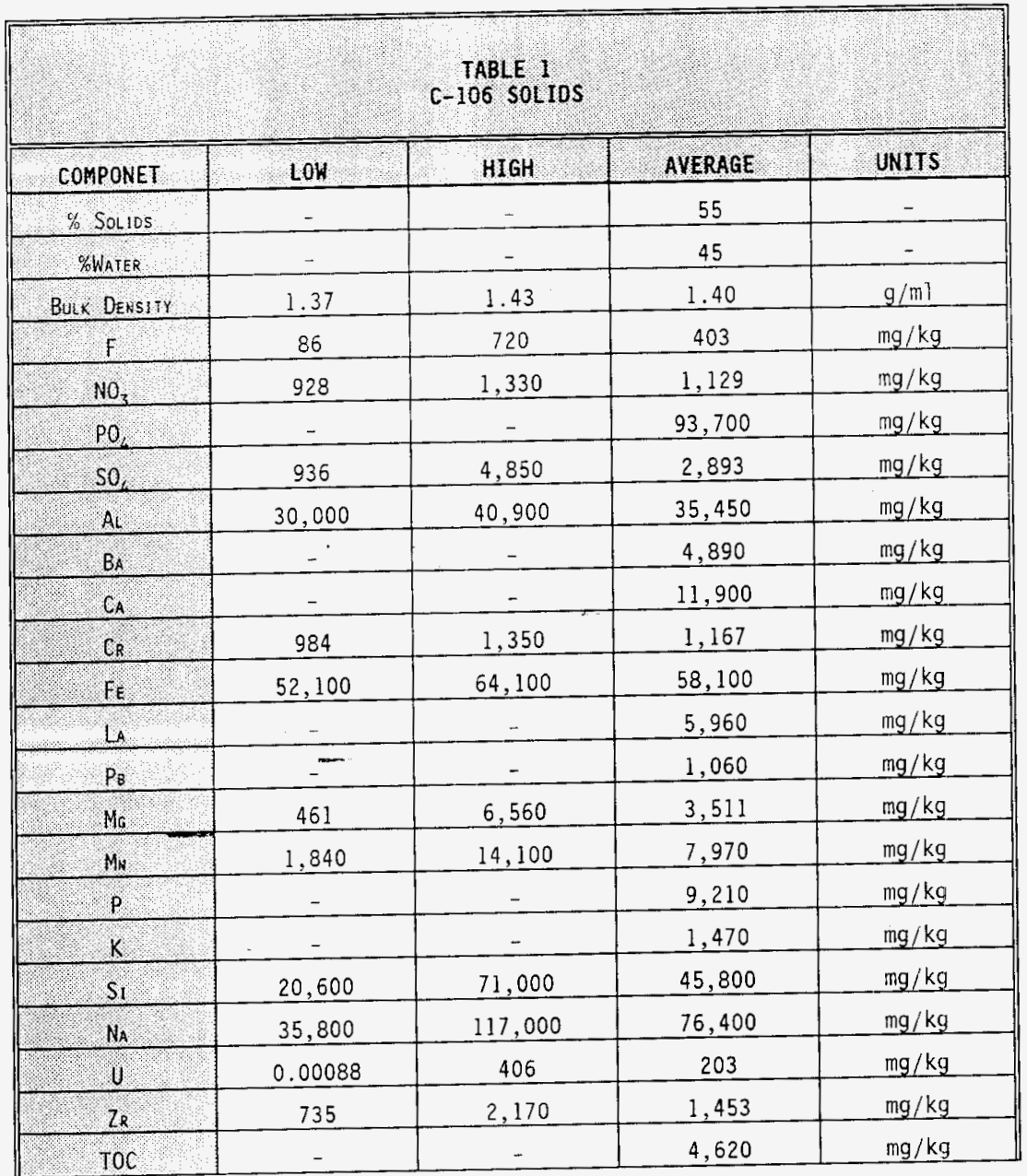


HNF-SD-W320-TI-008, Rev, 0

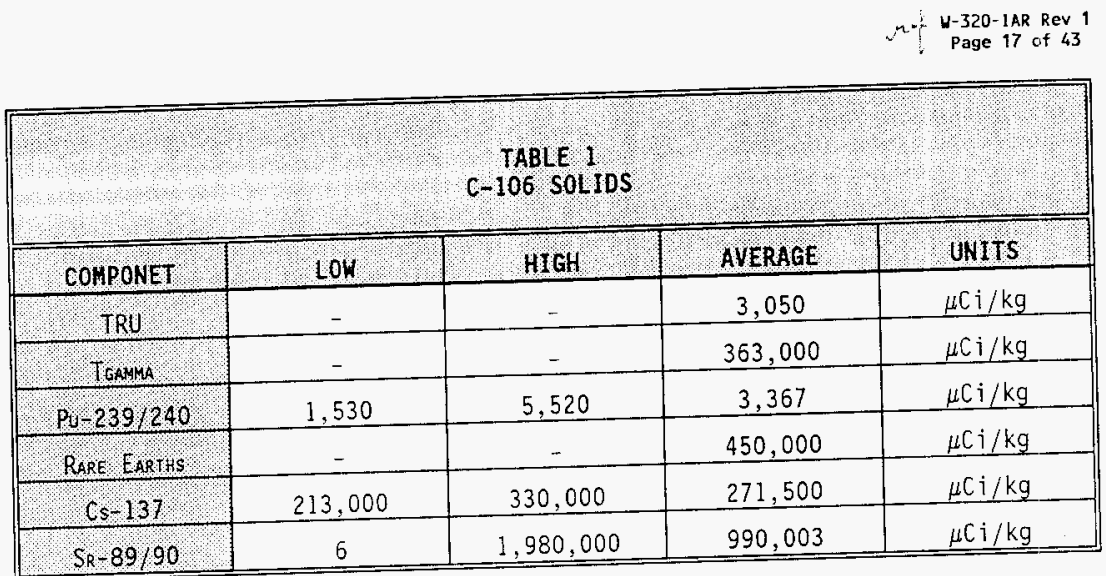




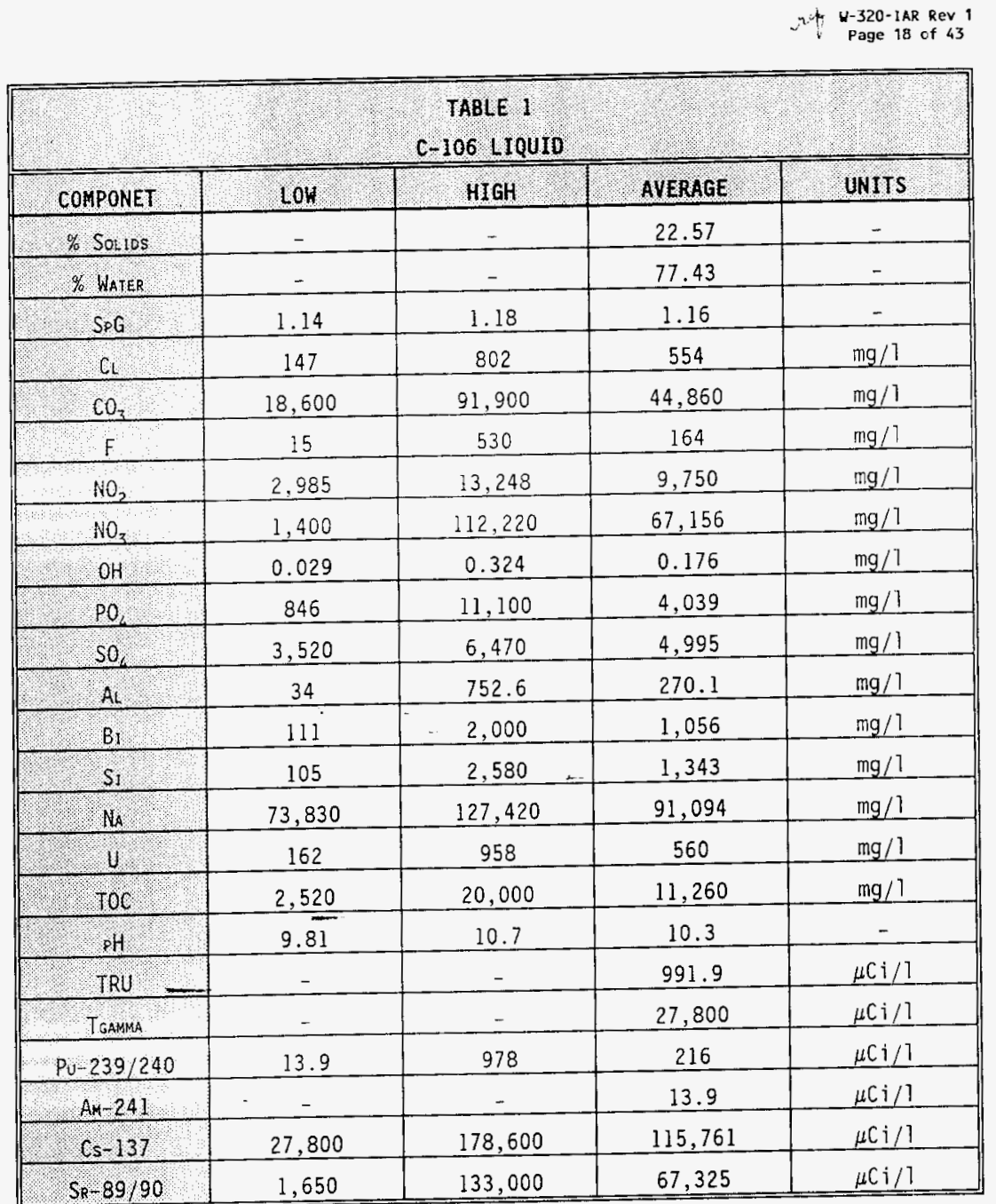


HNF-SD-W320-TI-008, Rev. 0

14-320-IAR ReV 1

Page 19 of 43

\section{Appendix III}

(Cáleulations List) 
HNF-SD-W320-TI-008, Rev. 0

R. U-320-IAR ReV 1

Page 20 of 43

\section{Calculations}

"Project $W-320$ Waste Retrieval for Tank 241-C-106 Process Pipe Stress Analysis", ICFKH Calculation W-320-27-013, 5/6/94.

"Project W-320 Waste Retrieval for Tank 241-C-106 Encasement Pipe Stress Analysis", ICFKH Calculation W-320-27-014, 5/3/94.

"Project W-320 Waste Retrieval for Tank 241-C-106 AY Farm Jumper Stress Analys is", W320-27-029, 2/28/95. 
HNF-SD-W320-TI-008, Rev. 0

n* H-320-IAR Rev 1

Page 21 of 43

\section{Appendix IV}

(Drawing List) 
Drawing List

H-818424, Project Site Plan.

H-2-818426, Sheet 1 of 2, Interfarm Transfer System Plan \& Profile. H-2-818426, Sheet 2 of 2, Interfarm Transfer System Plan \& Profile. H-2-818427, Sheet 1 of 2, 241-C-106 Transfer System Plan \& Profile. H-2-818427, Sheet 2 of 2, 241-C-106 Transfer System Sections. H-2-818428, Sheet 1 of 2, Interfarm Transfer System Sections \& Details. H-2-818428, Sheet 2 of 2, Interfarm Transfer System Sections \& Details. H-2-818431, Sheet l of 2, 241-C Tankfarm Site Plan. H-2-818432, 241-AY Tankfarm Site Plan. H-2-818434, 24l-AY-102 Transfer System Plan \& Profile. H-2-818448, Sheet 1 of 5, 24I-C-O6A Pump Pit Mod. Plan, Sections \& Details. H-2-818448, Sheet 2 of 5, 241-C-06A Pump Pit Mod. Plan, Sections \& Details. H-2-818448, Sheet 3 of 5, 241-C-06A Pump Pit Mod. Cover Block, Sections \& Details.

H-2-818448, Sheet 4 of 5, 241-C-06A Pump Pit Mod. Plan, Sections \& Details. H-2-818448, Sheet 5 of 5,241-C-06A Pump Pit Mod. Cover Block, Sections \& Details.

H-2-818450, Sheet 1 of 3, 241-C-06C Sluice Pit Mod. Plan, Sections \& Details. H-2-818450, Sheet 2 of 3, 24l-C-06C Sluice Pit Mod. Plan, Sections \& Details. H-2-818450, Sheet 3 of 3, 241-C-06C Sluice Pit Mod. Cover Block, Sections \& Details.

H-2-818453, Sheet 1 of 2, 241-AY-02A Pump Pit Mod. Plan, Sections \& Details. H-2-818453, Sheet 2 of 2, 241-AY-02A Pump Pit Mod. Pian, Sections \& Details. H-2-818454, Sheet 1 of 4, 241-AY-O2E Sluice Pit Mod. Plan, Sections \& Details. H-2-818454, Sheet 2 of 4, 241-AY-02E Sluice Pit Mod. Plan, Sections \& Details. 
H-2-818454, Sheet 3 of 4, 241-AY-02E S7uice Pit Mod. Cover Block, Sections \& Details.

H-2-818454, Sheet 4 of 4, 241-AY-02E Sluice Pit Mod. Plan, Sections \& Details. H-2-818458, Sheet 1 of 4, Misc. Elec conc. Pads Plans, Sections \& Details. $\mathrm{H}-2-818458$, Sheet 2 of 4 , Misc. Elec conc. Pads Plans, Sections \& Details. H-2-818458, Sheet 3 of 4, Misc. Elec conc. Pads Plans, Sections \& Details. H-2-818458, Sheet 4 of 4, Misc. Concrete Plans, Sections \& Details. H-2-818461, Misc. Elec conc. Pads Plans, \& Sections. H-2-818462, Sluicer Ring Embedment Details. H-2-818469, Overal] C-Farm Site Plan Tank C-106. H-2-818470, Sheet 1 of 4, Tank C-106 Ventilation Plan. H-2-818470, Sheet 2 of 4, Tank C-106 Ventilation Sections \& Details. H-2-818470, Sheet 3 of 4, Tank C-106 Ventilation Sections \& Details. H-2-818470, Sheet 4 of 4 , Tank C-106 Ventilation Sections \& Details. $\mathrm{H}-2-818477$, Pressure Relief Seal Loop Assembly.

H-2-818482, Sheet 1 of 3, Process Building Drain \& Supply Sections \& Details. H-2-818482, Sheet 2 of 3, Process Building Drain \& Supply Details. H-2-818482, Sheet 3 of 3, Process Building Drain \& Supply Details. H-2-818500, Seismic Restraint for slurry booster Pump. H-2-818501, Pump Pit AY-02A-U11-A- (C). H-2-818502, Pump Pit AY-02A-U3-U8-B. H-2-818503, Sheet 1 of 3 , S1uice Pit AY-02E-U-2(R-1D)-A-(B). H-2-818503, Sheet 2 of 3, Sluice Pit AY-02E-U-2(R-1D)-A-(B). $H-2-818503$, Sheet 3 of 3 , Sluice Pit $A Y-02 E-U-2(R-1 D)-A-(B)$. H-2-8]8505, Sheet 1 of 2, Jumper Assembly Pump Pit. H-2-818505, Sheet 2 of 2, Jumper Assembly Pump Pit. 
$\mathrm{H}-2-818508$, Sheet 1 of 3 , Jumper Assembly Pump Pit.

H-2-818508, Sheet 2 of 3, Jumper Assembly Pump Pit.

$\mathrm{H}-2-818508$, Sheet 3 of 3 , Jumper Assembly Pump Pit.

H-2-818509, Jumper Flushing Blank Head.

H-2-818510, Jumper Flushing Supply Head.

H-2-818512, Jumper Assembly Pump Pit.

H-2-818513, Jumper Assemb1y Pump Pit.

H-2-818515, Jumper Assembly Pump Pit.

H-2-818516, Jumper Assemb7y Sluice Pit.

H-2-818520, 24l-C Tank Farm.

H-2-818521, Tank 241-C-10б.

H-2-818522, Sheet 1 of 2, Pump Pit C-06A Plan, Sections \& Details.

H-2-818522, Sheet 2 of 2, Pump Pit C-06A Sections \& Details.

H-2-818523, Sluice Pit C-06C Plän, Sections \& Details.

$\mathrm{H}-2-818524$, Sheet 1 of 2, Jumper Arrangement Pump Pit 241-C-06A.

H-2-818524, Sheet 2 of 2, Jumper Arrangement Pump Pit 241-C-06A.

H-2-818526, Sheet 1 of 2, Jumper Arrangement Sluice Pit 241-C-06C.

H-2-818526, Sheet 2 of 2, Jumper Arrangement Sluice Pit 241-C-06C.

H-2-818532, Sheet 1 of 3, Support Details.

$\mathrm{H}-2-818532$, Sheet 2 of 3, Support Details.

H-2-818532, Sheet 3 of 3, Support Details.

$\mathrm{H}-2-818533$, Transfer Lines Plan \#l.

$\mathrm{H}-2-818534$, Transfer Lines Plan \#2.

H-2-818535, Transfer Line Details.

H-2-818537, Sheet I of 2, Distributor Assembly Plans, Elevation \& Details.

H-2-818537, Sheet 2 of 2, Distributor Assembly Plans, Elevation \& Details. 
H-2-818540, Tank 24l-AY-102 Plan.

H-2-818541, Tank 241-AY-102 Section \& Plan.

H-2-818542, Pump Pit AY-02A Plan Sections \& Details.

$\mathrm{H}-2-818543$, Sheet 1 of 2, Sluice Pit AY-02E Plan \& Sections.

H-2-818543, Sheet 2 of 2, Sluice Pit AY-02E Details.

H-2-818544, Sheet 1 of 2, Jumper Arrangement Pump Pit AY-02A.

H-2-818544, Sheet 2 of 2, Jumper Arrangement Pump Pit AY-02A.

H-2-818545, Jumper Arrangement Sluice Pit AY-02E.

H-2-818546, Sheet 1 of 2, Transfer Lines Support 241-C Farm.

H-2-818546, Sheet 2 of 2, Transfer Lines Support 241-C Farm.

H-2-818547, Transfer Lines Support "AY" Farm.

$\mathrm{H}-2-818548$, Sheet 1 of 2, Support Details.

H-2-818548, Sheet 2 of 2, Support Details.

H-2-818550, Piping Sluicer Drive Assembly.

H-2-818551, Piping Sluicer Assembly.

H-2-818558, Sheet 1 of $4, P$ \& ID Legend.

$\mathrm{H}-2-818558$, Sheet 2 of $4, P$ \& ID Equipment Identification.

$H-2-818558$, Sheet 3 of $5, P$ \& ID Details.

$\mathrm{H}-2-818558$, Sheet 4 of $4, P$ \& ID Interlock Schedule.

$\mathrm{H}-2-818559$, Sheet 1 of $5, \mathrm{P}$ \& ID Tank 241-C-106.

$\mathrm{H}-2-818559$, Sheet 2 of 5, P \& ID Tank 241-C-106.

$\mathrm{H}-2-818559$, Sheet 3 of $5, \mathrm{P}$ \& ID Tank 241-C-106.

$\mathrm{H}-2-818559$, Sheet 4 of 5, P \& ID Tank 241-C-106.

H-2-818559, Sheet 5 of 5, P \& ID Tank 241-C-106.

H-2-818560, Sheet 1 of $4, P$ \& ID Tank 24l-AY-102.

$\mathrm{H}-2-818560$, Sheet 2 of $4, P$ \& ID Tank 24l-AY-102. 
H-2-818560, Sheet 3 of $4, P$ \& ID Tank 24l-AY-102.

H-2-818560, Sheet 4 of 4, P \& ID Tank 241-AY-102.

H-2-81856l, Sheet $\mathrm{l}$ of $7, \mathrm{P} \&$ IO Tank 24l-C-106 HVAC.

H-2-818561, Sheet 2 of 7,P \& ID Tank 241-C-106 HVAC.

H-2-8I856I, Sheet 3 of 7, P \& ID Tank 241-C-I06 HVAC.

H-2-818561, Sheet 4 of 7, P \& ID Tank 24l-C-106 HVAC.

H-2-818561, Sheet 5 of 7, P \& ID Tank 24l-C-106 HVAC.

H-2-818561, Sheet 6 of 7, P \& ID Tank 24l-C-106 HVAC.

H-2-818561, Sheet 7 of $7, P$ \& IO Tank 241- - -106 HVAC.

H-2-818568, Installation Location Plan Tank 241-AY-102.

H-2-818569, Sheet 1 of 2, Installation Location Plan Tank 241-C-106.

H-2-818569, Sheet 2 of 2, Installation Location Plan Leak Detector Elements.

H-2-818575, Assembly Leak Detector Elements.

H-2-818599, C \& AY Farm Instrument. Sys Block Diagram.

H-2-818705, Sheet 1 of 2, Cathodic Protection Plan.

H-2-818705, Sheet 2 of 2, Cathodic Protection Details.

H-2-818706, Cathodic Protection Plan \#l.

H-2-818707, Cathodic Protection Plan $\$ 2$.

H-2-818708, Sheet 1 of 2 , Cathodic Protection Plan \#3.

$\mathrm{H}-2-818708$, Sheet 2 of 2 , Cathodic Protection Details.

H-2-818709, Cathodic Protection Details. 
HNF-SD-W320-TI-008, Rev. O

4. W-320-1AR ReV

Page 27 of 43

\section{Appendix V}

-(Drawings)

- 
HNF-SD-W320-TI-008, Rev. 0

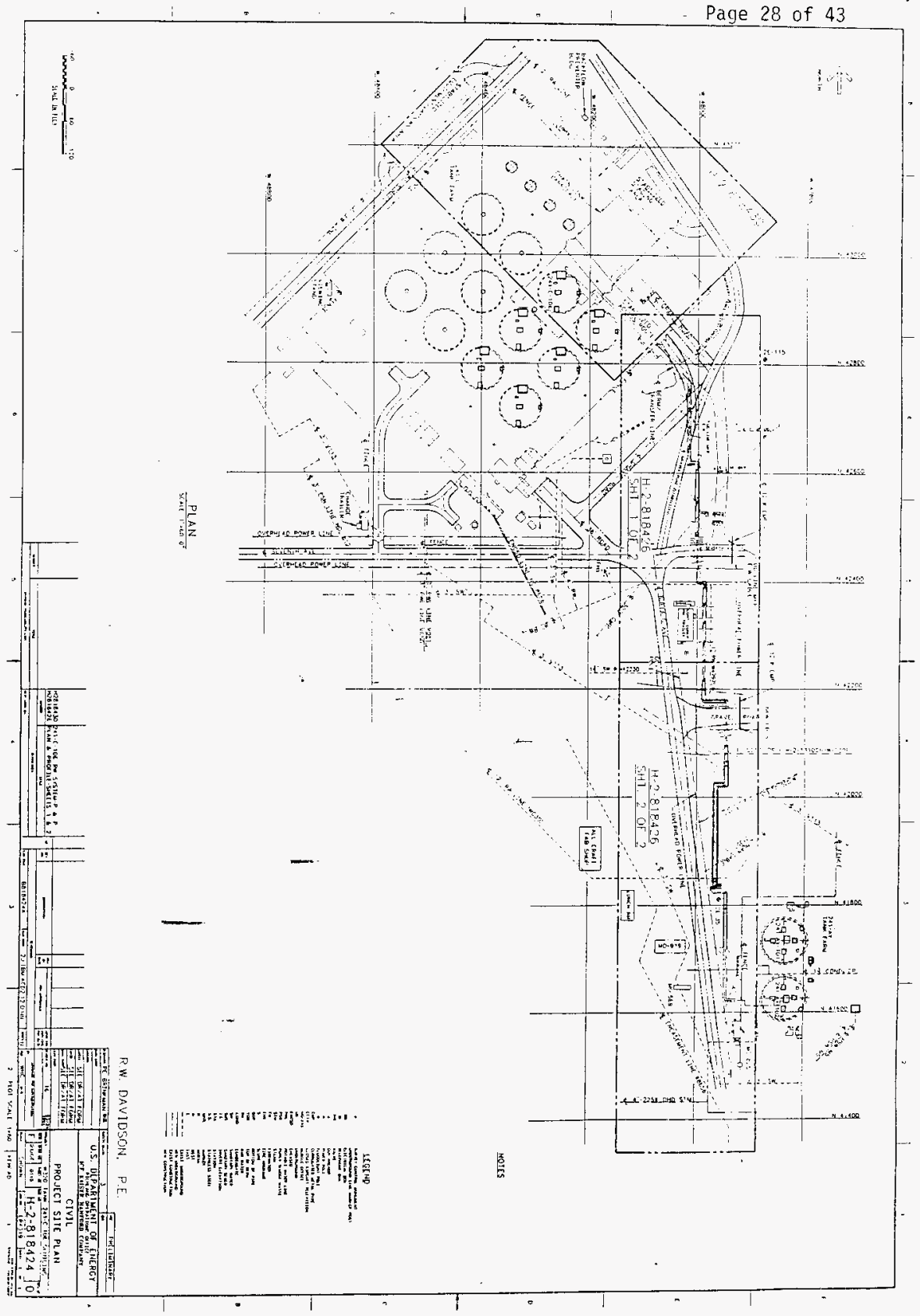


HNF-SD-W320-TI-008, Rev. 0

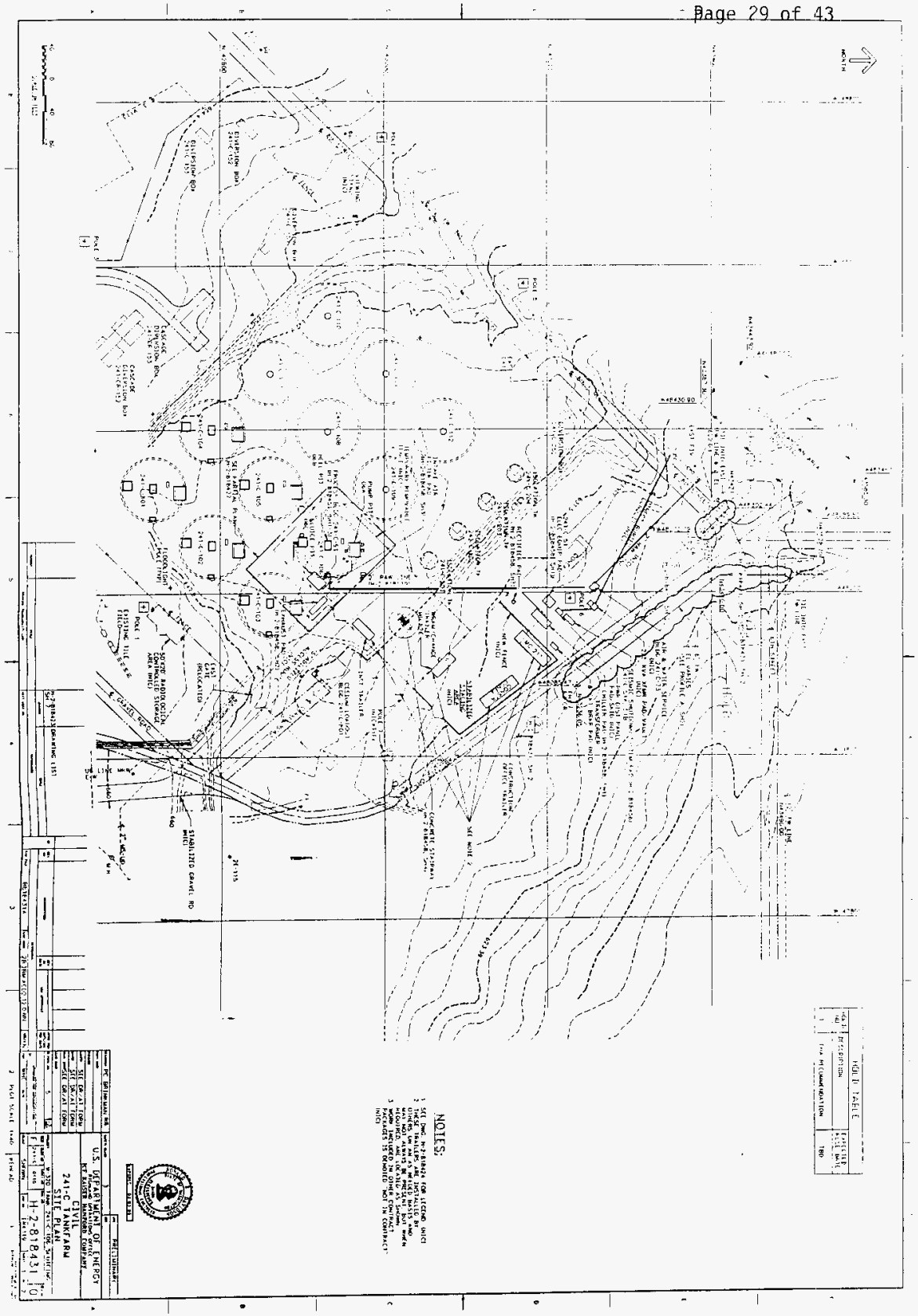


HNF-SD-W320-TI-008, Rev. 0

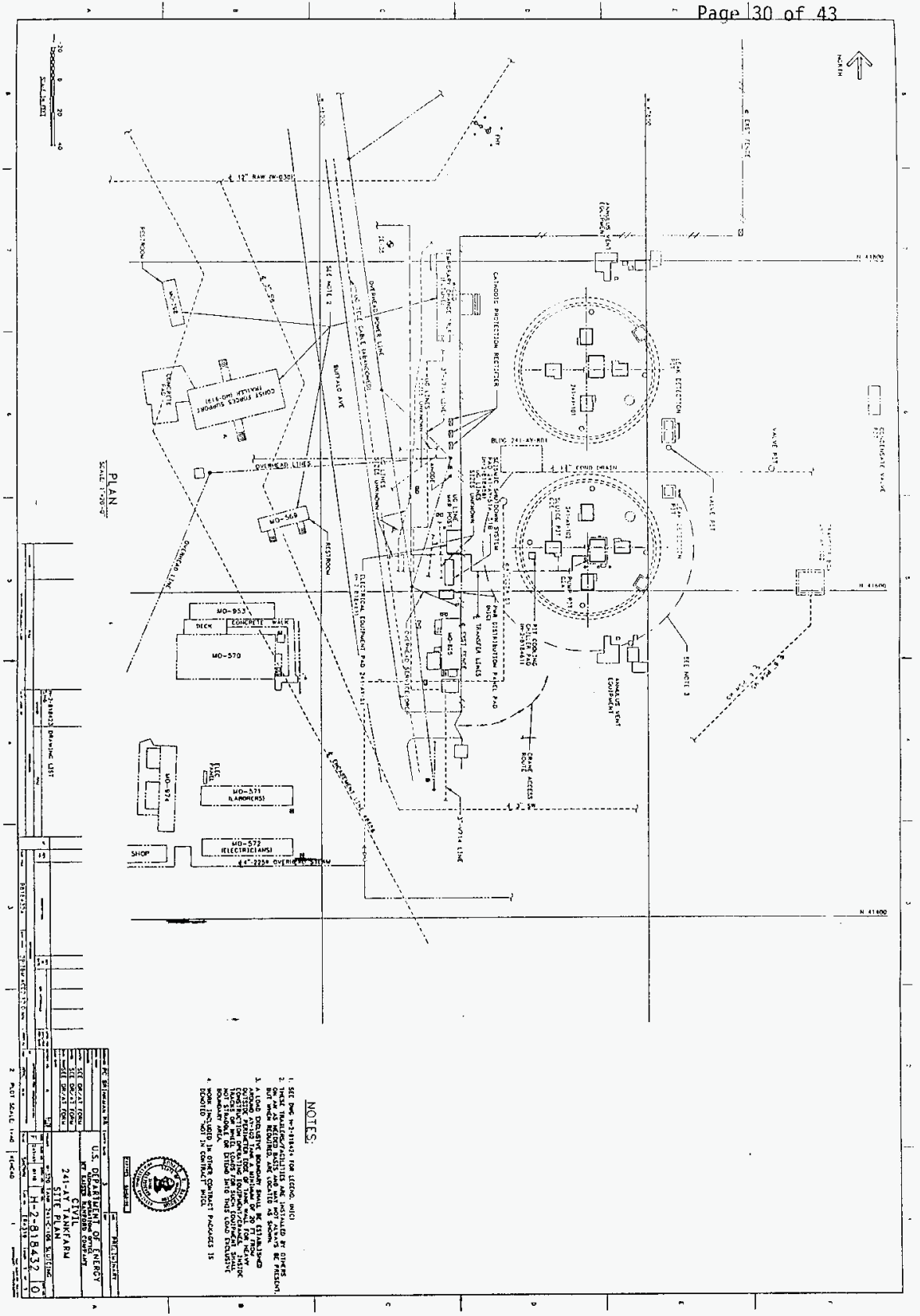




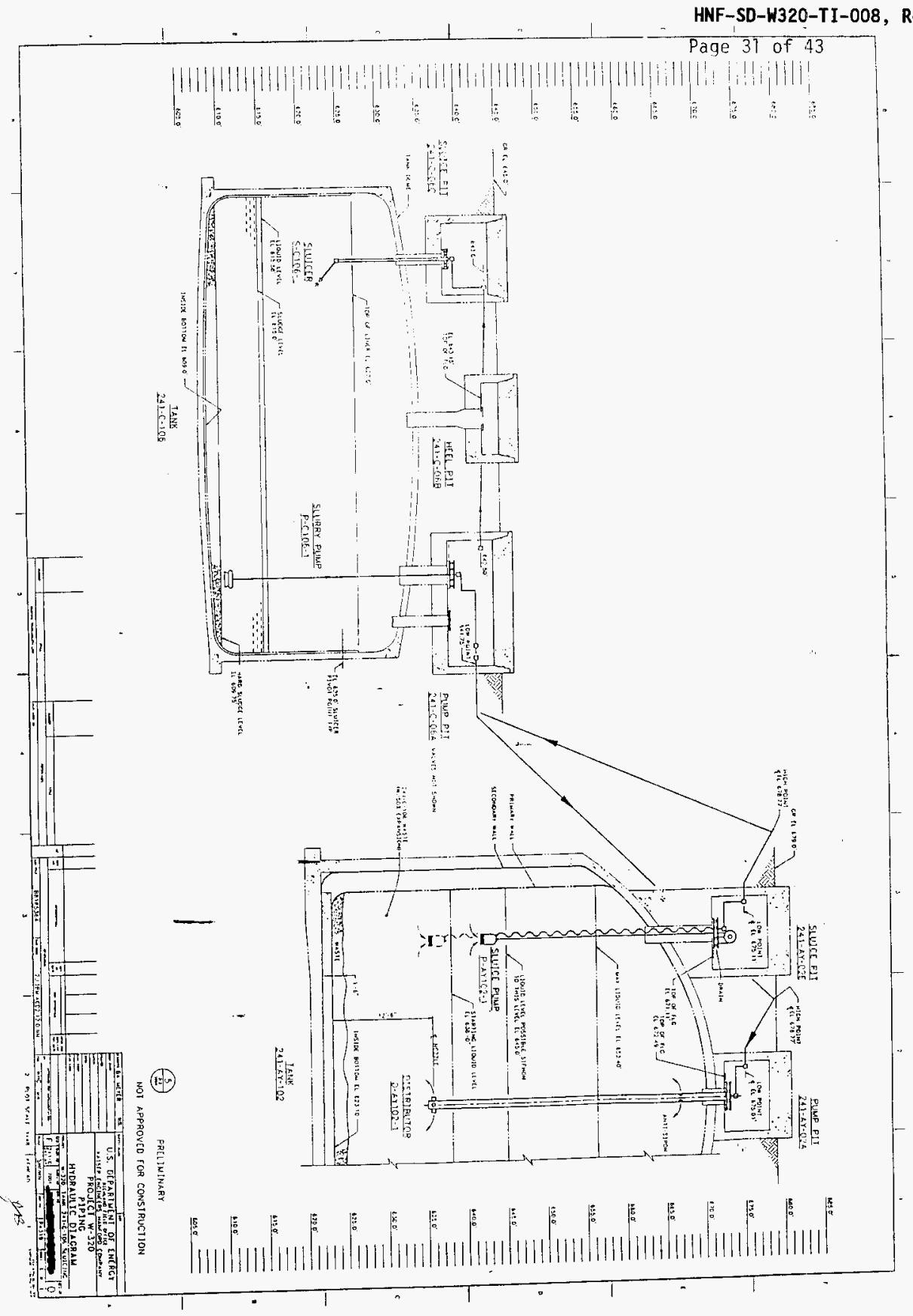


HNF-SD-W320-TI-008, ReV. 0

ref U-320-IAR-ReV 1
Page 32 of 43

\section{Appendix VI}

(Corrosion Study) 
HNF-SD-W320-TI-008, Rev. O

Page 33 of 43

EVALUATION REPORT ON THE W320 PROJECT

IN ACCORDANCE WTTH

WAC 173-303 $\$ 640$

prepared by

Dr. James R. Divine, PE

May 26, 1994

SCM Staff Placement Specialists, Inc. 7601 West Clearwater, Suite 302

KENNEWICK WA 99336
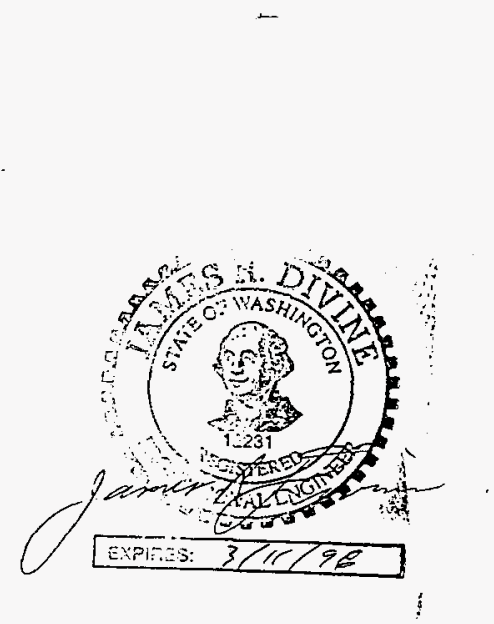
HNF-SD-W320-TI-008, Rev. O

Page 34 of 43

\title{
EVALUATION REPORT ON THE W320 PROJECT
}

\author{
LV ACCORDANCE WTTH
}

WAC $173-303 \S 640$.

\section{INTRODLCTION}

Westinghouse Hanford Company (WHC) is planning to transfer nuclear waste from a single-shell tank, Tank 241-C-106, to a newer double-shell tank, Tank 241-AY-102. The design is being prepared by ICF Kaiser Hanford (ICF IKH) under the title of Tank 241-C-106 Waste Retrieval Project W-320. Although the tanks are existing components, the transfer line is nev construction.

This report has been prepared to meet the Washington Administrative Code (WAC) 173-303 $\$ 640$ requirements for an independent review of the materials compatibility and corrosion protection design. It is concerned only with a review of the design of the connecting pipeline and does not apply itself to other requirements of $\$ 640$ on post-construction inspection.

\section{SUMMARY}

Overall the use of $304 \mathrm{~L}$ stainless steel is acceptable as the primary waste containment for the system as described. The use of carbon steel is also acceptable as the secondary containment. As long as the waste is maintained within the limits given the Hanford Technical Specifications for Double-Shell Tanks, it is not so corrosive to the carbon steel that failure of the primary containment would cause a secondary failure to be imminent.

The proposed cathodic protection system for the external surface of the carbon steel is satisfactory. Nevertheless, additional discussion should be provided in the design documents on the subject of the locations of anodes $A(46-40)$ through $A(46-46)$ to demonstrate to the general technical reviewer that the undefined underground lines that pass in the vicinity do not affect the protection of the pipeline in this project nor have a harmful impact on the existing lines. 


\section{REVIEIV}

\section{INTERNAL CORROSION}

\section{Design Standards}

There are no formal design standards from the corrosion standpoint for the construction of the transfer system. Nevertheless, the use of standard good practice construction procedures should be used to ensure high quality workmanship. These practices include the avoidance of dissimilar metal couples in locations where moisture is present, application of the proper welding procedures, welds that are gap free and do not form crevices, and of support pieces or covers that trap moisture. When welding the carbon steel line, care must be taken to ensure that carbon steel weld spatter does not contact the inner stainless steel line.

The cathodic protection of the pipeline has been designed, and should be expected to meet standard practice as referenced in section 16640, Cathodic Protection, of the Construction Procedures, and to conform with NACE International Recommended Practices RP0169-92² and RP0285-85. ${ }^{3}$

\section{Characteristics of Waste}

Table 1 is a modified version of the Tank 241-C-106 Headspace Characterization, Attachment 2, page D-10, of the Functional Design Criteria.4 Only selected values, the most important for corrosion and in the highest concentration, in the liquid in AY-102 were converted to molarity because that will probably represent the initial fluid; as the process proceeds, the composition will change though the project management ${ }^{3}$ has confirmed the waste will remain within the Hanford Technical Specifications for DoubleShell Tanks. The conversion of units from $\mathrm{mg} / \mathrm{kg}$ to molarity (MI) used data from the Process Flowsheet ${ }^{5}$ which gives the specific gravity of the liquid in AY-102 as 1.1. Data for C-106 are shown where they are high and significant.

The waste has little chToride, sufficient nitrite and hydroxide, and copious quantities of other anions. The concentrations will tend to increase in the liquid as the process continues and the temperature increases. Because of the requirements of the Hanford Technical Specifications, there will be minimum hydroxide and nitrite limits for the liquid which will ensure corrosion rates are small.

According to Estey the maximum design temperature is $180^{\circ} \mathrm{F}\left(\approx 80^{\circ} \mathrm{C}\right)$ and the normal operating temperature is $140^{\circ} \mathrm{F}\left(60^{\circ} \mathrm{C}\right)$. On the other hand, Ferlan ${ }^{6}$ states the operating temperature will be $180^{\circ} \mathrm{F}$. For purposes of this review, it will be assumed that the normal operating temperature will be $140^{\circ} \mathrm{F}$ inasmuch as Estey's is the later reference and defines the flowsheet.

The use of $304 \mathrm{~L}$ stainless steel at a temperature of $140^{\circ} \mathrm{F}$ with the anticipated waste concentrations is acceptable. ${ }^{7}$ There is significant experience at 
Table 1, Tank Compositions

\begin{tabular}{|c|c|c|c|}
\hline Components & $\begin{array}{c}\text { 241-AY-102 liquid } \\
(\mathrm{mg} / \mathrm{kg})\end{array}$ & $\begin{array}{c}\text { 241-AY-102 liquid } \\
(\mathrm{M})\end{array}$ & $\begin{array}{c}241-\mathrm{C}-106 \text { solid } \\
(\mathrm{mg} / \mathrm{kg})\end{array}$ \\
\hline chloride & 462 & 0.01 & \\
\hline \multicolumn{4}{|l|}{ cyanide } \\
\hline carbonate & 16965 & 0.26 & 18900 \\
\hline fluoride & 559 & 0.03 & \\
\hline nitrite & 11695 & 0.23 & 26320 \\
\hline nitrate & 50763 & 0.74 & 9738 \\
\hline hydroxide & 7609 & .0 .41 & \\
\hline phosphate & 974 & 0.01 & 93700 \\
\hline sulfate & 6277 & 0.06 & 18323 \\
\hline ammonia & 85 & & \\
\hline aluminum & i778 & & 87910 \\
\hline \multicolumn{4}{|l|}{ antimony } \\
\hline \multicolumn{4}{|l|}{ arsenic } \\
\hline barium & 6 & & 4890 \\
\hline \multicolumn{4}{|l|}{ bisnuth } \\
\hline \multicolumn{4}{|l|}{ boron } \\
\hline cadmium & 10 & & \\
\hline calcium & 217 & & 11900 \\
\hline chromium & 33 & & 2524 \\
\hline \multicolumn{4}{|l|}{ cobalt } \\
\hline copper & 7 & & \\
\hline iron & 10 & & 70304 \\
\hline lanthanum & 64 & & \\
\hline lead & 76 & & \\
\hline magnesium & 14 & & \\
\hline manganese & 258 & & \\
\hline mercury & & & 327 \\
\hline inickel & 65 & & \\
\hline \multicolumn{4}{|l|}{ palladium } \\
\hline \multicolumn{4}{|l|}{ phosphorus } \\
\hline potassium & 334 & & \\
\hline \multicolumn{4}{|l|}{ selenium } \\
\hline silicon= & 35 & & 45800 \\
\hline \multicolumn{4}{|l|}{ silver } \\
\hline sodium & 56748 & 2.2 & 76400 \\
\hline \multicolumn{4}{|l|}{ strontium } \\
\hline uranium & 20 & & \\
\hline zinc & 11 & & \\
\hline zirconium & 46 & & \\
\hline TOC & 5735 & & 4620 \\
\hline EDTA & 365 & & \\
\hline HEDTA & 296 & & \\
\hline oxalate+formate+citrate & 5074 & & 4620 \\
\hline
\end{tabular}


Hanford with $304 \mathrm{~L}$ stainless steel pipeliness. 9 and evaporators ${ }^{10}$ that show that a temperature of $140^{\circ} \mathrm{F}$ or less does not cause significant problems. However, if the temperature can exceed $180^{\circ} \mathrm{F}$, an evaluation of potential corrosion problems must be performed. A recommended test program would include:

A limited number of tests, specifically and electrochemical pitting scans and slow strain rate cracking tests, should be performed. Though the tests need to be defined in more detail if performed, an initial test matrix is:

1) AY-102 and C-106 waste compositions using two solutions; one which provides high chloride and one with low nitrate.

2) The solutions (1) with the minimum hydroxide, $0.01 \mathrm{MI}$,

3) Solutions (2) with no nitrate and nitrite, and

4) Tests with only chloride at the given concentrations and at $\mathrm{pH} 7$.

A temperature of $180^{\circ} \mathrm{F}$ should be used for any testing. Stainless steel $304 \mathrm{~L}$ in the sensitized condition should be used in the tests.

An acceptance test should be defined for the pipe that is purchased whether further testing is performed or not. Practice C in ASTM 262 is recommended and can be performed by the vendor; after any specified corrosion testing is completed, the results of the tests may cause a change in this recommendation.

According to the drawings, for example H-2-818426, the pipeline shall be sloped and will, as a consequence, gravity drain. This will eliminate the low spots which, as noted by Schwenk ${ }^{7}, 8$, have been a source of failures in stainless steel at Hanford. To ensure that residual solids do not deposit in the line, the line should be flushed. Flush water meeting the Hanford Technical Specifications for the Double-Shell tanks should be used; crevice corrosion and pitting can result if deposits are not removed. In no case shall raw water, if it is used, be allowed to remain standing in the line for any reason; there is a potential for microbially influenced corrosion.

Erosion corrosion is also a potential problem. As Smith \& Elmore ${ }^{11}$ noted, carbon steeluith a waste velocity of about $15 \mathrm{ft} / \mathrm{s}(4.6 \mathrm{~m} / \mathrm{s})$ can result in a erosion rate of about $3 \mathrm{mpy}(76 \mu / \mathrm{y})$. Other authors ${ }^{12,13}$ suggest that velocities over about $16 \mathrm{ft} / \mathrm{s}$ can cause stainless steel to lose its passivity and become very vilnerable to erosion and corrosion. Consequently the proposed flow rate $e^{5,6}$, $6 \mathrm{ft} / \mathrm{s}$ to $10 \mathrm{ft} / \mathrm{s}$, is acceptable. The Functional Design Criteria (FDC) ${ }^{14}$ indicates that in regions of the greatest flow obstruction, the erosion allowance will be 30 mpy; this value is acceptable and is expected to be conservative. No other reference to this number was found in the documents or drawings. Corrosion monitoring of the transfer line will be necessary because of the uncertainties in the erosion rate. Specifically, UT transducers, or equivalent, mounted at high risk elbows are recommended and acceptable.

Radiation dose rates 4 are stated to be much less than $1,000 \mathrm{rad} / \mathrm{h}$ and are therefore insignificant as regards internal corrosion. 


\section{EXTERNAL CORROSION}

\section{A List of factors}

Factors which are to be reviewed in accordance with $\$ 640$ include soil moisture, pH, sulfides, resistivity, structure to soil potential, influence of nearby metal structures, stray currents, and existing corrosion protection methods. The moisture content, $\mathrm{pH}$, sulfides, and resistivity were reported by Shannon \& Wilson. ${ }^{15}$ and are shown in Table 2. The other factors will be evaluated after construction.

Table 2, Concentrations of Chemical Species in the Soil

\begin{tabular}{|lc|}
\hline \multicolumn{1}{|c|}{ Species } & Concentration Range, $\mathrm{ppm}^{*}$ \\
\hline \multicolumn{1}{|c|}{} \\
\hline Bicarbonate & 6 to $\$ 2$ \\
\hline Carbonate & 0 to 20 \\
\hline Calcium & 3 to 24 \\
\hline Chloride & $<1$ to 5 \\
\hline Hardness, as CaCO 3 & 11 to 76 \\
\hline Magnesium & 0.8 to 3.6 \\
\hline Phosphate & 0.02 to 0.28 \\
\hline Sodium & 4 to 24 \\
\hline Conductance, tmho/cm & 47 to 240 \\
\hline Sulfate & 3 to 8 \\
\hline Sulfide & $<0.1$ \\
\hline Total Dissolved Solids & 35 to 180 \\
\hline Moisture. Fo & 4.3 to 14.8 \\
\hline pH & 8.8 to 9.6 \\
\hline * based on $100 \mathrm{~g}$ of soil extracted into $1 \mathrm{~L}$ of deionized water
\end{tabular}

The soil moisture content was, and typically is, less than about $10 \%$ except for one soil sample which exceeded that value. The sulfide level was low although it is known that sulfate reducing bacteria are common on the Hanford site and, under suitable conditions, sulfides could be generated. Generally the soil resistivity eeded $30,000 \mathrm{ohm}-\mathrm{cm}$; in those cases where it did not, the lower values may be artifacts of the nearby piping or localized salt concentrations and will have to be compensated for. The relatively high soil resistivity, the generally low solubles content of the soil, and the high $\mathrm{pH}$ suggest uniform corrosion will be small. However the sandy soil, variability of its characteristics, the historical data, and the possibility of microbially influenced corrosion suggest that pitting corrosion will be the most likely form of corrosion.

B External protection

The external piping will be coated with an epoxy which meets AWWA C213 standards. Typically such coatings can withstand radiation doses of approximately 50 to $100 \mathrm{Mrad}(0.5 \text { to } 1 \mathrm{MGy})^{26}$ but the acceptable dose is 
Page 39 of 43

dependent on temperature, humidity, and other environmental conditions. The temperature/dose combination should be evaluated if a life of more than one year at the anticipated radiation dose rates is needed.

iv Vehicle effects

The piping will be at a depth of approximately $4 \mathrm{ft} \pm 1 \mathrm{ft}, \mathrm{H}-2-818426$, sheet 2 of 2 . Originally an additional sleeve was promoted for the piping as it passed under roads. This addition has been eliminated which will assist in the application of cathodic protection. ${ }^{17}$

$\checkmark$ Design Considerations

The post-construction requirements by an independent expert such as:

c Pre-closure inspection including

i Welds

ii Punctures

iii Coating scrapes

iv Cracks

v Corrosion

vi Other damage

is not covered in this report.

Corrosion protection

The use of cathodic protection was recommended. ${ }^{15}$ It is also standard practice for Hanford underground piping.

A review of the proposed system was deemed satisfactory; indeed it provides an excess capacity for future expansion or added power as the coating degrades. Additional discussion on the effects of the existing underground piping in the vicinity of anodes $\mathrm{A}(46-40)$ through $\mathrm{A}(46-46)$, drawing $\mathrm{H}-2-818707$ is recommended to show the general reader that sufficient thought has been given to the cathodic protection system. The system is sufficiently overdesigned that the presence of foreign lines is not likely to be a problem.

However, if the anodes are too close to the pipes and the pipes are insufficiently insulated, the current drain may be larger than desirable. Hence some discussion of contingencies for relocating the anodes or other corrective action should be presented. An optional location of these anodes, perhaps west of the pipeline, should be discussed.

Containment -

Secondary systems, Compatibility with waste \& environmental conditions

Environmental concerns are discussed above in the section on External Corrosion. Corrosion in the annular space between the two pipes is discussed below. 
HNF-SD-W320-TI-008, Rev. 0

Page 40 of 43

\section{ANNULAR CORROSION}

Similar pipe-in-pipe designs have been used at Hanford for over about 10 years. In that time no problems have been reported.

As long as the annular space remains free of water, the corrosion of the carbon steel is expected to be sufficiently low. Due to the low number of anticipated operating cycles, no significant fretting corrosion is expected between the stainless steel spacers (welded to the stainless steel pipe) and the carbon steel during the proposed lifetime of the system. If the primary line fails, the waste, if within the Hanford Technical Specifications for Double-Shell Tanks, is expected to have little effect as far as uniform corrosion is concerned. However, because the external carbon steel line will not receive a post weld heat treatment, it is necessary that the waste meets these specifications to prevent the possibility of stress corrosion cracking.

\section{Inspections}

System inspections and documentation of the inspections will be required. They are not part of this document and are neither listed nor reviewed. 


\section{REFERENCES}

Page 4 l of 43

1 Khatak, H. S., N. S. Bharasi, and J. B. Gnanamoorthy, Iron Contamination Causes Stress Corrosion Cracking in Stainless Steels, Materials Performance (MP), Vol. 33, (Jure), pp. 56-57, 1994

2 RP0169-92, Control of Externol Cortecion on Underground or Submerged Metallic Piping Systems, NACE International, Houston TX

3 RP0285-\$5, Control of Enternal Corresion on Metallic Burted, Partially Buried, or Submerged Liquid Storcge Systems, NACE International, Houston TX

4 Bailey, J. W., Functional Design Criteria for Tonk 241-C-106 Waste Retrieval, Project W320, Revision 2, WHC-SD-W320-FDC-001, Westinghouse Hanford Co., Rich!and WA, January 1994.

5 Estey, S. D., Project W.320 Tcrk 241-C.106 Sluicing Process Flowsheet, WHC-SD-W 320 -TI-002, Rev. 0, Westinghouse Hanford Co., Richland WA, March 1994

6 Ferlan, K. B., Tank 241.C.106 Sluicing Letter Report, WHC-SD-WM-ES-234, Rev. 2, Westinghouse Hanford Co., Richland WA, May 1993

7 Sedriks, A. J., Stress.Corrosion Cracking of Stainless Steels, In: Stres5-Corrosion Cracking, R. H. Jones, Editor, ASM International, Materials Park OH, 44073-0002, 1992.

8 Schwenk, E. B., Anolysis of Leakage Failure in Liquid Waste Transfer lines SV 402 and 406, Pacific Northwest Laboratory, Richland, WA, March, 1984

9 Schwenk, E. B., Metcllurgical Anclysis of Leak Failure of Waste Transfer Line V-398, Pacific Northwest Laboratory, PNL-4771, Richland, WA, June, 1983

10 OhJ, P. C. and W. C. Carlos, Hanford High-Level Waste Evaporator/Crystallizer Corrosion Evaluation, Presented at Corrosion 94, Baltimore MD, Feb. 28 - March 4, 1994. NACE International, Houston TX.

11 Smith, H. D., and M. R Elmore, Corrosion Studies of Carbon Steel Under Impinging Jets of Simulated Slurries of Neutralized Current Acid Waste (NCAW) and Neutralized Cladding Removal Woste (NCRW), PNL-7816, Pacific Northwest Laboratory, Richland WA, January 1992

12 Levy, A. V., Erosion/Corrosion of Metals in Cocl Liquefoction Environments., Univ. of California, Berkeley. Corrosion S0/157, NACE, Houston, TX.

13 Madsen, B. W., Measurement of Wear and Corrosion Rates Using a Novel Slurry Wear Test Appcratus., Albany Research Center, Bureau of Mines, U.S. Department of the Interior, P.O. Box 70, Albany, OR 97321, Corrosion 86/235, NACE, Houston, TX,

14 Reference 3, Appendix A1.2

15 Final Repert of Geotechnical Engineering Studies IV 320 Waste Retrieval and Sluicing System 200 East Area, Hanford Site, Shannon \& Wilson, Inc., April 1994

16 Fouracre, R. A., A. Al-Attabi, H. M. Banford, M. J. Given, and D. J. Tedford, Radiation Effects in Epoxy Resin System: Gamma Rays, Neutrons and High Energy Electrons, Presented at the 1990 Conference on Electrical Insulation and Dielectric Phenomena, Pocono Manor, PA, October 28-31, 1990.

17 Jones, C. D., Personal Communication to J. R. Divine, May 12, 1992. 


\section{APPENDIX I}

\section{SUMDIARY CHECKLIST FOR WAC 173-303 $\$ 640$}

I1 Applicability All Tarks that store or treat dangerous wastes except as noted.

(Exceptions - dry tanks inside building with impermeable floor.)

q2 Existing Tank Integrity

a All Systems assess by January 12, 1990

b Assess within 12 months

c Must consider

i Design standards

ii Characteristics of $w a s t e(s)$, past \& future

iii Existing corrosion protection measures

iv Documented age of system

$v$ Leak test

A Leak test non-enterable

d Requirements if tank leaks

e Schedule for assessment

q3 New System

a Assessment Obtain IQRPE assessment that system has integrity and can store the waste. Include:

i

$\mathrm{ii}$

iii

Design standards

Dangerous characteristics of waste

External corrosion

A List of factors

B External protëction

iv Vehicle effects

$\checkmark$ Design Considerations

b Assessment schedule

c Pre-closure inspection IQII or IQRPE

i Welds

ii Punctures

iii Coating scrapes

iv Cracks

$\mathrm{v}$ Corrosion

d Backfill

$v i$ Other damage

e Tightness

f Support Ancillary equipment

$g$ Corrosion protection either (a)(iii) or other, includes installation supervision

$h$ Records .-

94 Containment \& detection of releases

a Secondary containment

b Secondary requirements

c Secondary systems must

i Be compatible with waste \& environmental conditions

i i Have suitable foundation

iii Detect leaks in $\leq 24 \mathrm{~h}$

iv Have proper slope/design

d Secondary Requirements not listed here 
e Secondary containrents

i Meet external liner requirements: not listed here

ii Vaults must meet: not listed here

iii Double wall tank requirements

$f$ Exception to b \& $c$ above

g Variances

h Variance Procedures

\$5 General operating requirements includes prevention of fume release from tanks of EHW details not listed

¿6 Inspections

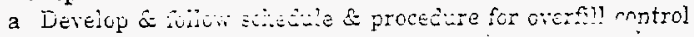

b Inspect daily

i Above ground portions

ii Leak detection data

iji Surrounding area \& materiais of constriction

c CP system if presert

i Operation within 6 months after installation and annually thereafter

ii Sources of impressed current inspected and/or tested bimonthly

d Documentation of inspections

I7 Response to leaks includes IQRPE certification before return to service

I8 Closure \& post-closure care

I9 Special requirements Ignitable or reactive waste

\$10 Special requirements Incompatible wastes

I11 Special requirements Dangerous wastes 